\title{
Predicting Corporate Financial Distress in Sri Lanka With Reference to Z-Score Model
}

\author{
K.G.M. Nanayakkara ${ }^{1}$, A.A. Azeez ${ }^{2}$ \\ ${ }^{1}$ Department of Commerce \& Financial Management, \\ Faculty of Commerce \& Management Studies, University of Kelaniya, Sri Lanka \\ madurikan@gmail.com \\ ${ }^{2}$ Department of Finance, Faculty of Management \& Finance, \\ University of Colombo, Sri Lanka \\ aazeez72@yahoo.com
}

\begin{abstract}
Financial Distress is a problem spread all over the world from the history. Even though there are ample research studies on this area, the empirical results on this area provide inconclusive results. The majority of the research works focused only on the bankruptcy and not on the financial distress. Hence, the main purpose of this study is to develop a better financial distress prediction model for Sri Lankan companies using the Z-score model. Multivariate Discriminate Analysis (MDA) was used as the analytical technique and simultaneous estimation method has used to enter the variables in the analysis. The study has examined four accounting ratios for 134 distressed and non-distressed companies from 2002 to 2011. The study has found that the derived model which consists of four accounting ratios is capable of predicting financial distress of quoted public companies in Sri Lanka with 76.9\% accurate one year prior to distress. Further, the model has the financial distress predicting ability of $74.6 \%$ and $67.2 \%$ two years and three years prior to distress respectively. This model can be used to assist investors, creditors, managers, auditors and regulatory bodies in Sri Lanka to predict the financial distress.
\end{abstract}

Key words: Financial Distress, Multivariate Discriminant Analysis, Z-Score, Accounting Ratios, Sri Lanka.

\section{Introduction}

Financial distress is a problem common to almost all the markets in the world. The term financial distress or failure of companies has flooded in the world especially in the United States of America from 1930's. But even before, the problem of distress caused some large companies to file for bankruptcy. Firstly in 1930, the Bureau of Business Research (BBR) 
studied and published a mechanism in order to identify the failure of firms based on accounting ratio analysis. With the publication of BBR report, many other researchers have attempted to search most accurate ways to predict the company failure. Especially, in the consequences of the Asian crisis in 1997, understanding the potential for corporate distress has become even more important in light of company financial distress and bankruptcy in emerging stock markets (Samarakoon \& Hasan, 2003). While the majority of researches have focused on the area of business failure, certain studies focus on the area of financial distress. This study focuses financial distress and not the company failure or filing for bankruptcy.

Why has the financial distress become a problem to answer? When a company is suffering with financial distress situation, there is a problem for the employees of such company as well as for the shareholders, lenders and the other stakeholders. It badly affects the job security of managers and employees and stakeholders' equity position and claims of lenders since their claims are not guaranteed (Bum, 2007). In order to achieve all those stakeholders' objectives, it is very much important for the companies to avoid financial distress. In this context, the question of how we predict financial distress or what reveals the credit risk of firms is a significant issue.

Even though there are ample studies available internationally, only one published study in Sri Lanka (Samarakoon \& Hasan, 2003) could be found in the area of predicting financial distress. They empirically tested the three versions of Altman's Z-Score model with the financially distressed companies in Sri Lanka. According to them US based Altman Z"Score model has a remarkable degree of accuracy in predicting distress in the year prior to distress. But their study has not been adjusted and tested the loadings (weights) of the accrual based ratios for the Sri Lankan context and the conclusion is given based on the original Zscore formula which was derived from USA bankrupted companies. This study claims that the classification accuracy declines when the financial information in the two consecutive years prior to distress is used. But there is no any test on the predicting accuracy of the model for more than two consecutive years. According to Bellovary et al (2007) a model to become more valuable it should be able to accurately predict bankruptcy earlier. Further, "an investor will certainly care not only about imminent failure, but rather will want to get senses well in advance which are the firms that are most likely to fail" (Campbell et al, 2011, p 02). However, Samarakoon \& Hasan (2003) conclude that the Z-Score model is a suitable model in predicting financial distress in Sri Lanka. Further, according to the companies act no 07 of 2007, a company should be satisfied with the solvency test before making any distribution to 
the shareholders. In satisfying the solvency test it should consider the working capital requirements and the equity position of the company. Hence the importance of accounting data in predicting the financial distress is evident owing to the company law of Sri Lanka.

In this context there is an urgent need to develop the most prominent Altman's Z-score model in a manner suitable to emerging economies like Sri Lanka. Therefore the objective of this study is to examine the discriminating power of financial distress using the variables of the Altman's Z-score model and develop a suitable model for Sri Lanka, which could provide sense in advance about the financial distress of companies. In order to develop the model the study has analyzed the selected variables from year 2002 to 2011 of 67 distressed and 67 nondistressed companies. Multivariate Discriminant Analysis (MDA) used as the analytical technique and simultaneous estimation method used to enter the variables in the analysis. The study has tested up to three years prior to distress in order to get an idea about the possibility of using the model in advance. In addition, the result of the model validated using the cross validation method. Our results provide robust evidence that the derived model which consists of four accounting ratios is capable of predicting financial distress of quoted public companies in Sri Lanka with $76.9 \%$ accuracy one year prior to distress. Further, the model has correctly classified the cases with $74.6 \%$ and $67.2 \%$ accuracy in two years and three years prior to distress respectively. The study also reveals that the companies with negative cutoff value fell into distress zone while companies with positive cutoff values fell into safety area. Hence, we suggest that the companies with cutoff values closer to zero should be considered for mitigating actions for financial distress.

The balance part of the paper is organized as follows. The next section deals with prior research studies in relation to prediction of corporate failure using accounting ratios. The methodology section discusses the selected variables, dataset, model and method of model validation. The fourth section presents the empirical results and data analyses. Finally, conclusion of the study is presented.

\section{Literature Review}

In 1930, Bureau Business Research (BBR) published their study of simple ratio analysis based on failing industrial firms and they introduced the ratios which could be used by the companies to apply as the indicators of the weakness. This ratio analysis as a technique for predicting failures were used by few other researchers (eg: FitzPatrick: Smith \& Winakor: Merwin: Jacendoff, as cited in Bellovary et al., 2007), and they introduce various ratios as the 
best indicators of company failure. Beaver (1966) uses univariate analysis as the statistical tool rather just limiting to a simple ratio analysis with the motive to provide an empirical verification of the usefulness of the accounting data. This study used ratios of Cash flow to total debt, Net income to total assets, Total debt to total assets, Working capital to total assets, Current ratio and No-credit interval and concludes that the all ratios do not predict equally well and the Cash Flow to Total Debt (CFTD) ratio has the excellent discriminatory power throughout the five year period while the predictive power of the liquid asset ratios is much weaker. He further concludes that the ratios do not predict the failed and non failed firms with the same degree. However, the ratio analysis can be useful in the prediction of failure for at least five years before failure (Beaver, 1966). Beaver's univariate approach to analyze financial distress was seldom followed because, while one ratio would indicate failure another could indicate non-failure (Sharma, 2001).

Even though univariate analysis emphasizes the importance of ratio analysis in predicting corporate failure those studies fail to present the order of their importance. Each study indicates the different ratios as being the most effective indication of impending problems (Altman, 1968). Since Multivariate Discriminant Analysis (MDA) ${ }^{1}$ is able to provide the order of the importance of the variables (respective weights) and is able to analyze the entire variable profile of the object simultaneously rather than sequentially, researchers move to MDA and other advanced statistical techniques rather than depending on univariate analysis.

Multivariate Discriminant Analysis was firstly applied as a statistical technique for predicting bankruptcy by Altman in 1968 to overcome the limitations in univariate analysis. Sixty six manufacturing firms (33 failed and 33 non - failed) were used to test twenty two financial ratios under the five standard ratio categories of liquidity, profitability, leverage, solvency, and activity. The Discriminant function was developed with weights to the finally selected five ratios of working capital to total assets, retained earnings to total assets, earnings before interest and taxes to total assets, market value of equity to book value of total debt, and sales to total assets. It gives cut-off points (optimum $\mathrm{Z}$ value) which enables to categorize firms under bankrupt area, safety area and grey area ${ }^{2}$. Using the model bankruptcy can accurately be predicted up to two years prior to actual failure and the accuracy decrease rapidly after the second year (Altman, 1968). Using the Multivariate Discriminant analysis as the analytical

\footnotetext{
${ }^{1}$ Multivariate Discriminant Analysis (MDA) is a technique available to classify the groups which are in categorical by nature.

2 The area between the two cut-off values in the study is defined as the "zone of ignorance" or "grey area" because of the susceptibility to error classification (Altman, 1968).
} 
tool Taffler \& Tishaw $(1977)^{3}$ develops a Z-score model in order to predict company failure based on UK companies. Profit before taxes to current liabilities, current assets to current liabilities, current liabilities to total assets, and no credit interval are found as the most important financial ratios which gives one year prior prediction accuracy.

Altman (1983) studies the original Z score model targeting private firms (Z' score model or private firm model ${ }^{4}$ ) by substituting the book value of equity for the market value keeping other variables constant. This revised model with book value of equity to book value of total liabilities probably less reliable than the original, but only slightly less (Altman, 2000). Altman (1993) further revise the original Z-score model as Z"-score model ${ }^{5}$ using nonmanufacturing companies. Since the Sales to total assets ratio is an industry sensitive variable, it is excluded in the modified model in order to minimize the potential industry effect. Since Mexican firms are issuing Eurobond denominated in US dollars, Altman, Hartzell \& Peck (1995) applied the Z" Score model for emerging markets. Even though the emerging market credits may initially be analyzed in a way similar to the US firms, it is not often possible to build a model for emerging markets based on a sample from that country due to the lack of credit experience (Altman et al., 1995). They developed Emerging Market Scoring model (EMS) based on the calibration of the EMS scores with the US bond - rating equivalents. Same variables in the Z"-Score model were used in EMS model with a constant term of +3.25 in order to standardize the scores. The study reports that the modified ratings have proven accuracy in anticipating both down grades and defaults and upgrades.

Yap, Yong \& Poon (2010) develop a model to predict company failure for Malaysia based on manufacturing companies. The study analyses 16 financial ratios under the MDA and finally constructs a strong discriminant function with 7 ratios which has a predictive accuracy for five years prior to actual failure. Among the seven ratios, two ratios (RETA and WICTA) are in the three versions of Altman's Z-Score model. Maina \& Sakwa (2010) also identify the RETA as a better predictor. However, according to Hillegeist et al (2004) RETA is not a better predictor for financial distress.

In Sri Lanka, Samarakoon \& Hasan (2003) test the original Altman's Z-score models and concludes that the third version of score model (Z"-score model) gives the highest overall success rate and it seems that Z-score models have a very good potential in predicting

\footnotetext{
${ }^{3}$ A most prominent model developed based on UK companies and all the variables used are different from Altman's Model.

${ }^{4}$ This is the second version of the Altman's Z-score model

${ }^{5}$ This is the third version of the Altman's Z-Score model
} 
financial distress of companies in emerging markets, but with a declining overall accuracy at the two consecutive years prior to distress. This study provides evidence that Altman's Zscore model is a suitable analytical tool for Sri Lankan companies in predicting financial distress. But no further evaluations have been done using a latest dataset to derive a model specific to Sri Lanka with a high predicting accuracy level.

\section{Research Methodology}

This section describes the data set, selected variables, and the statistical models. In this study financial distress is defined as the companies suffering with losses continuously for three years or more and/or, suffering with negative cash flow position continuously for three years or more and/ or, have a negative net worth continuously for three years or more. Dependent variables are dichotomous as financially distressed or non- distressed. The companies which satisfied one of these three criteria are defined as 'financially distressed' company.

This study employs the financial ratios used under the Altman's model. Table 1 present those ratios along with their definitions. When using the Altman's Z-score model, we excludes the sales to total assets, which is used as a predictor in the original model developed for manufacturing companies, because it is an industry sensitive variable. We incorporates only the variables in the Altman's 1993, Z"-score model. The same definitions given in Altman $(1968 ; 1983 ; 1993)$ for the predictors [(Working Capital to Total Assets (WICTA), Retained Earnings to Total Assets (RETA), Earnings Before interest and Taxes to Total Assets (EBITTA), Market Value of Equity to Book Value of Total Debts (MVEBVTD)] are used for this study. These ratios are incorporated in to the studies of company failure by many research studies to date. Further, previous study in Sri Lanka relating to corporate failure or bankruptcy by Samarakoon \& Hasan (2003) also identifies these variables as sound predictors. 
Table 1: Operationalization of the variables

\begin{tabular}{|l|l|l|l|}
\hline & Variables & Indicators & Measurement \\
\hline $\begin{array}{l}\text { Dependent } \\
\text { variables }\end{array}$ & $\begin{array}{l}\text { Financially distressed } \\
\text { companies } \\
\text { Financially not } \\
\text { distressed companies }\end{array}$ & $\begin{array}{l}\text { Net worth } \\
\text { Annual profitability } \\
\text { Soundness of the Cash flow }\end{array}$ & $\begin{array}{l}1=\text { if distressed, } \\
0=\text { otherwise }\end{array}$ \\
\hline $\begin{array}{l}\text { Independent } \\
\text { variables }\end{array}$ & $\begin{array}{l}\text { Accrual based financial } \\
\text { ratios }\end{array}$ & $\begin{array}{l}\text { Profitability/Leverage } \\
\text { Liquidity } \\
\text { Profitability/Efficiency } \\
\text { Liquidity/Efficiency }\end{array}$ & $\begin{array}{l}\text { RE/TA } \\
\text { WIC/TA } \\
\text { EBIT/TA } \\
\text { MVE / BV of TD }\end{array}$ \\
\hline
\end{tabular}

The data are collected from the annual reports of the listed companies in the Colombo Stock Exchange for the period from 2002 to 2011. There are 20 industries and 246 companies quoted in CSE as of $31^{\text {st }}$ March, 2011. In determining the population Banking, Finance and Insurance industry is excluded since it has separate characteristics than the other industries by its nature. Out of the remaining 206 quoted public companies, the companies that satisfied one of the above mentioned three criteria have been selected as distressed companies. Certain companies which satisfied the criteria as distressed have to be ignored from the sample due to the unavailability of previous years data, listed in CSE at least not more than three years from the distressed year, or unavailability of healthy company for matched sample (ex: Information technology industry). Finally, the study used total sample size of 134 quoted public companies registered in CSE including 67 number of financially distressed companies and the same number of non-distressed companies selected based on the industry and/or asset size as the matched sample following the literature (eg. Altman, 1968; Beaver, 1966; Altman, Baidya \& Dias, 1979 etc) in order to discriminate the two groups ${ }^{6}$.

Data are collected for each company in the sample (one year, two year and three year separately). As mentioned in Altman (1968) and later studies, data collected for the nondistressed companies from the same years as of relative distressed companies. Data of one year prior to distress were considered in developing the discriminant function while two year

\footnotetext{
${ }^{6}$ Refer appendix A for the sample of two groups
} 
and three year prior data are used to test the predicting ability of the derived function in advance ${ }^{7}$.

The following discriminant function is used for the analysis ${ }^{8}$.

$\mathrm{Z}=\alpha+\beta_{1} \mathrm{X}_{1}+\beta_{2} \mathrm{X}_{2}+\beta_{3} \mathrm{X}_{3}+\beta_{4} \mathrm{X}_{4}$

Where; $\mathrm{Z}=$ Discriminant score value,

$\mathrm{X}_{1}=$ WICTA,$\quad \mathrm{X}_{3}=$ EBITTA,

$\mathrm{X}_{2}=$ RETA,$\quad \mathrm{X}_{4}=$ MVEBVTD.

To proceed with the analysis the study has tested major two assumptions to be satisfied to incorporate MDA as a statistical tool namely, multivariate normality of the independent variables, and unknown (but equal) dispersion and covariance structures (equal covariance matrices). In analyzing the model simultaneous estimation method is applied to see the discriminating power of the predicting variables identified by Altman in his third version of the Z-score model.

After developing the discriminant function any one can use the final coefficients in the function to determine the $\mathrm{Z}$-score value for any observation in practice. In order to determine the relevant zone the function should derive a common cutting score. Optimum cutting score could be calculated considering the defined prior probabilities of the groups (Altman, 1968; Hair et al., 2011). Since there is an equal prior probability, the following formula is applied to calculate the cutting score (Optimum Z-score) of the discriminant function ${ }^{9}$.

$$
\mathrm{Z}_{\mathrm{CE}}=\left(\mathrm{Z}_{\mathrm{A}}+\mathrm{Z}_{\mathrm{B}}\right) / 2
$$

Where,

$$
\begin{aligned}
& Z_{C E}=\text { Critical cutting score value for equal group sizes } \\
& Z_{A}=\text { Centroid for Group } A, Z_{B}=\text { Centroid for Group } B .
\end{aligned}
$$

\footnotetext{
${ }^{7}$ Majority of the prior studies tested the models for two years and few studies tested for three to five years prediction accuracy.

${ }^{8}$ In Altman's original model the constant term cannot be seen due to the statistical package (which was developed by W. Cooley and P. Lohnes) used to develop the model.

${ }^{9}$ This formula could be applied only with the equal prior probabilities.
} 
In order to identify the predicting ability of the model the classification matrix ${ }^{10}$ was developed for the sample using SPSS software and to construct the classification matrix each observation were classified into distress or non-distress following the rule in Hair et al., (2011) as follows.

Classify a company into group distress if $\mathrm{Zn}<\mathrm{Zct}$

Classify a company into group non-distress if $\mathrm{Zn}>\mathrm{Zct}$

Where,

$\mathrm{Zn}=$ Discriminant $\mathrm{Z}$ score for the individual,$\quad \mathrm{Zct}=$ Critical cutting score value

After calculating the hit ratio ${ }^{11}$ the standard of comparison are estimated. Majority of the researchers accept the hit ratio if it is $25 \%$ greater than the standard of chance (Burns \& Burns, 2009; Hair et al., 2011), and we adopt the same method. In addition, the Press's Q statistic is applied as a test to ensure the classification accuracy more statistically. Once the model developed for predicting company failure, we used cross-validation method to externally validate the model.

\section{Empirical Results}

This section discusses descriptive statistics, test of assumptions, estimation results, validation of model, analysis of advance classification accuracy of the model and discussion of results.

Table 2 indicates the descriptive statistics of all four variables in the study under two main groups in equal size as financially distressed and non-distressed companies. Even though there are high standard deviations in variables the mean differences among the two groups are statistically significant according to $\mathrm{F}$ test (Table 4).

\footnotetext{
${ }^{10}$ Classification matrix is a table with rows of dependent categories and columns of predicted categories (Burns \& Burns., 2009).

${ }^{11}$ Percent correctly classified the two groups by the function
} 
Table 2: Descriptive Statistics

\begin{tabular}{|c|c|c|c|c|c|c|c|c|}
\hline \multirow[b]{2}{*}{ Variable } & \multicolumn{4}{|c|}{ Group 1} & \multicolumn{4}{|c|}{ Group 2} \\
\hline & Mean & $\begin{array}{l}\text { Standard } \\
\text { Deviation }\end{array}$ & Minimum & Maximum & Mean & $\begin{array}{l}\text { Standard } \\
\text { Deviation }\end{array}$ & Minimum & Maximum \\
\hline WICTA & .0109 & .2583 & -.5180 & .6501 & .1712 & .2517 & -.3026 & .7993 \\
\hline RETA & -.0574 & .2935 & -.4961 & .6122 & .1933 & .1912 & -.2634 & 6693 \\
\hline EBITTA & .0279 & .0837 & -.0843 & .2440 & .1061 & .0753 & -.0800 & .2491 \\
\hline MVEBVTD & 2.9290 & 2.3761 & -1.77 & 8.31 & 4.8626 & 1.8754 & 1.66 & 10.53 \\
\hline $\begin{array}{l}\text { No of } \\
\text { observations }\end{array}$ & 67 & & & & 67 & & & \\
\hline $\begin{array}{l}\text { Note: Group } \\
\text { Retained Ea } \\
\text { MVEBVTD }\end{array}$ & $\begin{array}{l}\text { Distres } \\
\text { gs to To } \\
\text { Market V }\end{array}$ & $\begin{array}{l}\text { Group } 2= \\
\text { l Assets, E } \\
\text { lue of Equi }\end{array}$ & $\begin{array}{l}\text { Non-distress } \\
\text { 3ITTA = Ear } \\
\text { y to Book va }\end{array}$ & $\begin{array}{l}\text { WICTA }=\mathrm{V} \\
\text { ings Before } \\
\text { ue of Total }\end{array}$ & $\begin{array}{l}\text { orking C } \\
\text { Interest a } \\
\text { ebts }\end{array}$ & $\begin{array}{l}\text { pital to Tota } \\
\text { hd Taxes to }\end{array}$ & $\begin{array}{l}\text { Assets, RE } \\
\text { otal Assets, }\end{array}$ & $\mathrm{TA}=$ \\
\hline
\end{tabular}

\section{Test of Assumptions}

The study firstly analyzed the assumptions of normality, the equal covariance, multicollinearity and differences between the groups. Outliers in the variables trimmed prior to the estimation.

Kolmogorov-Smirnov test results become insignificant for each variable by accepting the null hypotheses of the test and plots of the Q-Q diagram are laid on or nearly on the diagonal line. Assumption of equal covariance matrix tested using Box's M statistics and the Log determinants within the groups. With the variables in the model, the test of log determinants satisfied the test of equal covariance with similar log determinants for the two groups. Meanwhile, box's M test do not support the assumption with $26.59 \mathrm{M}$ value and 2.57 F value and significant at $\mathrm{p}$ value of 0.004. However, according to Burns \& Burns, (2009) with significant $\mathrm{M}$ statistic the assumption could be hold if the log determinants become similar. Accordingly, even the Box's M test is not in favor of the equal covariance matrix, we are satisfied with the assumption under the test of log determinants.

The results of correlation matrix are reported in Table 3. These results show the absence of multicollinearity among the independent variables. 
Table 3: Correlation Matrix

\begin{tabular}{lrrrr}
\hline & RETA & WICTA & EBITTA & MVEBVTD \\
\hline RETA & 1.000 & - & - & - \\
WICTA & .273 & 1.000 & - & - \\
EBITTA & .283 & .300 & 1.000 & - \\
MVEBVTD & .487 & .366 & .226 & 1.000 \\
\hline
\end{tabular}

To proceed with the discriminant analysis, another criterion of significance differences between groups on each predictor should be satisfied. This could be tested using descriptive statistics (group means) and values in ANOVA Table (Wilks' Lambda) (Hair et al., 2011; Burns \& Burns, 2009). When smaller the Wilks' Lambda, the independent variable will be more important for discriminating purpose (Yap et al, 2010). Further, it could be identified the most significant differences between groups on each predictor by comparing the mean values of independent variables in the groups.

Accordingly, the group means differences are analyzed using descriptive statistics for two models separately. As shown in Table 4, WICTA which has highest Wilks' Lambda is significant with lowest $\mathrm{F}$ value of 13.22. When comparing the group means it can be seen a significant difference between mean values of two groups for all four variables in the model. Further it indicates that all the variables are significant under the equality test of group means.

Table 4: Group Descriptive Statistics and Test of Equality of Group Means

\begin{tabular}{lccccc}
\hline & \multicolumn{2}{c}{$\begin{array}{c}\text { Dependent variable } \\
\text { Group Means }\end{array}$} & \multicolumn{2}{c}{ Test of Equality of Group Means } \\
\cline { 2 - 6 } $\begin{array}{l}\text { Independent } \\
\text { Variables }\end{array}$ & $\begin{array}{c}\text { Financially } \\
\text { distress } \\
\text { companies }\end{array}$ & $\begin{array}{c}\text { Financially } \\
\text { not distress } \\
\text { companies }\end{array}$ & $\begin{array}{c}\text { Wilks' } \\
\text { Lambda }\end{array}$ & F Value & Significance \\
& $\begin{array}{c}\text { Group 1) } \\
(\mathrm{n}=67)\end{array}$ & $\begin{array}{c}\text { (Group 2) } \\
(\mathrm{n}=67)\end{array}$ & & & \\
\hline RETA & -.057428 & 0.193318 & .794 & 34.318 & .000 \\
WICTA & .010958 & 0.171202 & .909 & 13.219 & .000 \\
EBITTA & .027982 & 0.106161 & .804 & 32.264 & .000 \\
MVEBVTD & 2.928994 & 4.862555 & .828 & 27.336 & .000 \\
\hline
\end{tabular}




\section{Estimation of the model}

After satisfying all the required criteria in discriminant analysis the discriminant function was estimated using the variables in the Altman's third version of the $\mathrm{Z}$-score model. The function derived using the canonical discriminant function coefficients. The results are shown in Table 5. Accordingly, the variables of Retained earnings to total assets and Earnings before interest and taxes to total assets are the most important predictors in the model ${ }^{12}$. Further resulting a lowest Wilks' Lambda (Table 4) among the four predictors in the model the EBITTA and RETA shows the relative importance of them.

\section{Model}

$\mathrm{Z}=-1.185+1.790$ RETA + 0.319 WICTA + 6.603 EBITTA + 0.152 MVEBVTD

Table 5: Discriminant Function and discriminant loadings

\begin{tabular}{lccc}
\hline & Discriminant Function & $\begin{array}{c}\text { Structure } \\
\text { Matrix }\end{array}$ \\
\hline $\begin{array}{c}\text { Independent } \\
\text { Variable }\end{array}$ & Unstandardized & Standardized & $\begin{array}{c}\text { Discriminant } \\
\text { Loadings }\end{array}$ \\
\hline Constant & -1.185 & & \\
RETA & 1.790 & .443 & .773 \\
WICTA & .319 & .081 & .480 \\
EBITTA & 6.603 & .526 & .749 \\
MVEBVTD & .152 & .325 & .690 \\
\hline
\end{tabular}

As shown in the Table 6, the canonical correlation of 0.551 with an eigenvalue of 0.435 of the model suggests that the model explains $30.3 \%$ variation in the grouping variable of financially distressed or non-distressed companies. While Wilks' Lambda shows that the overall model is unexplained about the variance in the grouping variable by $69.7 \%$, the chisquare of 46.99 and the significant $\mathrm{p}$ value indicate a highly significant function in the model. With a significant function $(\mathrm{p}=.000)$ it could ascertain the overall model fit using the cutting scores and the classification accuracy of the model.

\footnotetext{
${ }^{12}$ RETA and EBITTA shows the highest discriminant loading values and MVEBVTD become the third important predictor in the model.
} 
Table 6: Eigenvalue and Wilks' Lambda

Percent of variance

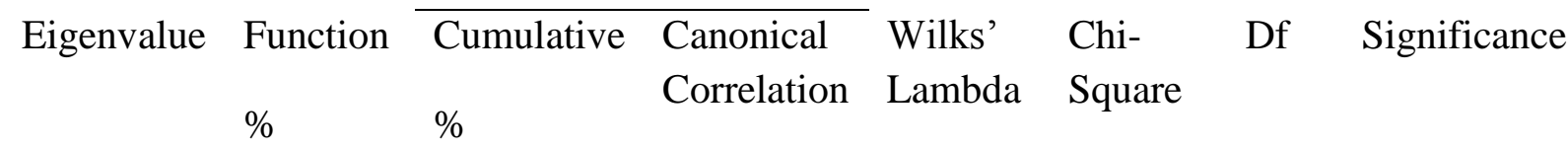

\begin{tabular}{|c|c|c|c|c|c|c|c|}
\hline .435 & 100.0 & 100.0 & .551 & .697 & 46994 & 4 & .000 \\
\hline
\end{tabular}
prior probabilities are equal.

$\mathrm{Z}_{\mathrm{CE}}=\{0.655+(-0.655)\} / 2$

$\mathrm{Z}_{\mathrm{CE}}=0$

According to the critical Z-score the companies that are using the model with $<0 \mathrm{z}$-score value (negative score) fell into distress group after one year and $>0 \mathrm{Z}$-score (positive score) fell into non-distress group ${ }^{13}$. Based on this cutoff value the model has classified each case in the analysis ${ }^{14}$, and classification results are shown in Table 7.

Based on the critical Z-score the companies are classified in the sample into two groups as distressed and non-distressed to check the classification accuracy and the misclassification cost of the model. Table 7 indicates that the model is able to correctly classify the distress companies with $70.1 \%$ and non-distress companies with $83.6 \%$ accuracy. Further in overall the model has a classification accuracy of $76.9 \%$. Hence, the hit ratio of the model is $76.9 \%$. According to the results the cost of misclassification could be analyzed using type 1 and type II error. Model has correctly classified non-distressed companies than the distressed companies.

Table 07: Classification results: Hit Ratio of the model

\begin{tabular}{lllllll}
\hline & \multicolumn{5}{c}{ Predicted Group Membership } \\
\cline { 2 - 7 } & 0 & 1 & Total & 0 & 1 & Total \\
\hline $\begin{array}{l}\text { 0= Non- } \\
\text { distress }\end{array}$ & 56 & 11 & 67 & 83.6 & 16.4 & 100 \\
$\begin{array}{l}\text { 1=Distress } \\
\text { 76.9\% of original grouped cases correctly classified [(103/134) x 100]. }\end{array}$
\end{tabular}

\footnotetext{
${ }^{13}$ At the presence of a constant term the cutoff score between the two groups would be zero since the constant term will standardizes the cutoff score at zero when the sample sizes of the two groups are equal (Altman, 2000)

${ }^{14}$ Refer Appendix B and C for the case wise results and graphical representation of classification in to two groups
} 
The results of both tests used in the study to accept the hit ratio [standard of comparison by chance $(25 \%$ into the standard of chance $=50 \% \times 1.25)$ and the Press's Q statistics] provide evidence in favor of the derived model as a discriminate model with better prediction accuracy (i.e., $25 \%$ into the standard of chance $=50 \% \times 1.25<$ hit ratio and the Press's Q statistics, 38.68).

\section{Validity of the Model}

Since there is a model with better prediction accuracy the validity of the model is tested using cross validation method. According to the cross validation results the model has predicted the cross validation cases $76.1 \%$ accurately. Further in cross validation the distressed firms are correctly classified by $70.1 \%$ and non distressed firms are correctly classified by $82.1 \%$. Even with a repeated process of withholding the cases of the sample better accuracy results are obtained and hence we can satisfy with the validity of the model.

\section{Analysis of Advance Classification Accuracy of the Model}

All most all the studies in the field of predicting bankruptcy or company failure examined the advance predicting ability of the developed models. According to the Campbell et al (2011) a model which has predicting ability of the failure for a longer horizon will provide investors a sense well in advance.

This study also examined the advance prediction ability of the model for two years and three years before the financial distress of companies. According to the results the model has predicted by $74.6 \%$ accurately for two years before the distress and by $67.2 \%$ accurately for three years before the distress. Both percentages exceed the criterion of standard of chance and hence we can conclude in favor of the model with its advance predicting ability. The results are shown in Table 08 . 
Table 08: Classification results: Hit Ratio for two years and three years before distress

\begin{tabular}{|c|c|c|c|c|c|c|c|}
\hline \multirow{3}{*}{$\begin{array}{l}\text { Year Before } \\
\text { Failure }\end{array}$} & & \multicolumn{6}{|c|}{ Predicted Group Membership } \\
\hline & & \multicolumn{3}{|c|}{ Number } & \multicolumn{3}{|c|}{ Percentage } \\
\hline & & 0 & 1 & Total & 0 & 1 & Total \\
\hline \multirow[t]{2}{*}{ Two* } & $\begin{array}{l}0=\text { Non- } \\
\text { distress }\end{array}$ & 55 & 12 & 67 & 82.1 & 17.9 & 100 \\
\hline & $1=$ Distress & 20 & 47 & 67 & 29.9 & 70.1 & 100 \\
\hline \multirow[t]{2}{*}{ Three** } & $\begin{array}{l}0=\text { Non- } \\
\text { distress }\end{array}$ & 51 & 16 & 67 & 76.1 & 23.9 & 100 \\
\hline & 1=Distress & 18 & 49 & 67 & 26.9 & 73.1 & 100 \\
\hline
\end{tabular}

\section{Discussion of the Results}

Based on the results of model we can see better predicting results up to three years in advance. RETA shows the most discriminating ability over the other three variables with the highest discriminant loading. EBITTA and MVEBVTD has resulted the second and third importance respectively in the model. WICTA has identified as the least important variable in the model as same as in the Altman's study. Anyway, all four variables reflected with statistically significant results and hence identified as important in predicting financial distress. RETA shows the most discriminating power in Altman's function also with the highest significant $\mathrm{F}$ value under the test of univariate significance (Altman, 2000). Yap et al (2010) and Maina \& Sakwa (2010) also identify the RETA as a better variable in discriminant analysis. Meanwhile, Hillegeist et al (2004) find this variable as an insignificant variable in predicting failure.

However, when we compare the results of original Altman's Z" Score model test done by Samarakoon \& Hasan (2003), our model in this study fails to outperform the classification results. Their model classified the overall cases accurately by $81 \%$ with a low Type I error while our model derived in the study has classified its overall cases correctly only by $76.9 \%$. 
Even though the result is up to satisfactory level based on standard of chance and Press's Q statistics, not accurate than the coefficients with the original model.

When considering the advance classification accuracy of the model for two year and three year, this study provides better results over the results of Samarakoon \& Hasan (2003). The model of this study classified the cases accurately two year before and three year before the distress by $74.6 \%$ and $67.2 \%$ respectively. According to the Samarakoon \& Hasan (2003) the Altman's third version has accurately predict the distress only by $68 \%$ in the two year before the distress. They did not test the model for more than two years and concludes that the accuracy will decline after two consecutive years before the failure. Further, according to Altman (1968) the bankruptcy prediction model (Altman's Z-score) is an accurate predictor up to two years prior to bankruptcy and that the accuracy diminishes substantially as the lead time increases. In our study, even though the model accuracy has declined with the lead time increases the prediction accuracy of the model up to three year before the distress is statistically accepted under the press's Q statistic.

\section{Conclusion}

The objective of this study was to develop better financial distress prediction model for Sri Lankan quoted companies using Z-score model for a recent company sample through Multivariate Discriminate Analysis. This study has used the accounting data from 2002 to 2011 in order to analyze the discriminant power of the variables and to alter the Altman's Zscore model with context specific loadings.

Based on the results of the models in the analysis this study has found that the model with accrual based ratios as a better predictor of financial distress up to three years prior to distress. It is an advantage of using this model since it has a high advance predicting ability. Retained earnings to Total Assets, is able to predict firm's financial distress more accurately than the other variables. It can be concluded that the derived model which consists of four accounting ratios is able to predict financial distress of Quoted public companies in Sri Lanka by $76.9 \%$ accurately. The model has the financial distress predicting ability of $74.6 \%$ and $67.2 \%$ for two years and three years before distress respectively. Hence this model can be identified as an even better model that could be applied for advance prediction of firm's financial distress except for the banking, finance and insurance industry. In addition, the study has revealed that the companies with negative $(<0)$ cutoff score are in the zone of distress while companies with positive $(>0)$ cutoff score are in the zone of safety. 
Finally it can be concluded that the Z-score model under Multivariate Discriminant Analysis is still a valid model for predicting financial distress in the context of Sri Lanka. Though there are criticisms over MDA, this study reveals the importance and validity of the technique in finance arena. Additionally, the study has empirically developed context specific coefficients and a cutoff score which is more use full in the practice. Our model can be used to assist investors, creditors, managers, auditors and regulatory bodies in Sri Lanka to predict the financial distress.

\section{References}

Altman,E.I.(1968). Financial ratios, Discriminant analysis and the prediction of corporate bankruptcy, The Journal of Finance, 23, 589-609.

Altman,E.I.(1983). Corporate financial distress: A complete guide to predicting, avoiding and dealing with bankruptcy, New York: John Wiley \& Sons

Altman,E.I.(1993). Corporate financial distress and bankruptcy, 2nd ed., New York: John Wiley \& Sons

Altman, E.I. (2000). Predicting financial distress of companies: Revisiting the Z-score and ZETA models, Journal of Banking and Finance

Altman, E.I., Baidya, T.K.N., \& Dias, L.M.R. (1979). Assessing potential financial problems for firms in Brazil, Journal of Banking and Finance, 10(2), 9-24.

Altman, E. I., Hartzell, E.J., \& Peck,M. (1995). Emerging market corporate bonds: A scoring system, New York: Saloman Brothers Inc.

Barnes, P.(1987). The analysis and use of financial ratios: A review article, Journal of Business Finance and Accounting, 14(4), 449-461.

Beaver, W. H. (1966). Financial ratios as predictors of failures, Journal of Accounting Research, 4, 71-111.

Bellovary.J., Giacomino, D., \& Akers, M. (2007). A review of bankruptcy prediction studies: 1930 to present, Journal of Financial Education, 33.

Bum, J.K. (2007). Bankruptcy prediction: Book value or market value?. Paper presented at 2007 APRIA Annual Meeting. Retrieved from http:// www.rmi.nccu.edu.tw/apria/docs.

Burns, R.B., \& Burns, R.A. (2009). Research Methods and Statistics Using SPSS, (epublication, 1st ed), Sage Publication Limited. 
Campbell, J.Y., Hilscher, J., \& Szilagyi,J. (2011), Predicting financial distress and the performance of distressed stocks, Journal of Investment Management, 9 (2), 1-21.

Hair, J.F., Black, W.C., Babin, B.J., Anderson, R.E., \& Tatham, R.L.(2011). Multivariate Data Analysis, (6th ed), Pearson.

Hillegeist, S. A., Cram, D.P., Keating, E.K., \& Lundstedt, K.G. (2004). Assessing the probability of bankruptcy, Review of Accounting Studies, 9 (1), 5-34.

Maina, F.G., \& Sakwa, M.M. (2010). Understanding financial distress among listed firms in Nairobi stock exchange: A quantitative approach using the Z-score multi- discriminant financial analysis model, Scientific Conference Proceedings, Jumo Kenyatta University of Agriculture and Technology, Nairobi, Kenya.

Samarakoon, L.P., \& Hasan, T. (2003). Altman's Z-Score models of predicting corporate distress: Evidence from the emerging Sri Lankan stock market, Journal of the Academy of Finance, 1, 119-125.

Sharma, D.S. (2001). The role of cash flow information in predicting corporate failure: the state of the literature, Journal of Managerial Finance, 27(4), 3-28.

Taffler,R.J., \& Tishaw,H. (1977). Going, going, gone: Four factors which predict, Accountancy, 88, 50-54.

Yap, B.C.F., Yong, D.G.F., \& Poon, W.C. (2010). How well do financial ratios and multiple discriminant analysis predict company failure in Malaysia, International Research Journal of Finance and Economics, 54, 166-175.

Appendix A: Sample

\begin{tabular}{|l|l|l|l|l|}
\hline & Distressed Companies & $\begin{array}{l}\text { Distressed } \\
\text { year }\end{array}$ & & $\begin{array}{l}\text { Non-Distressed companies (Matched } \\
\text { sample) }\end{array}$ \\
\hline $\mathbf{0 1}$ & Coco Lanka Plc & $2006 / 2007$ & $\mathbf{6 8}$ & Tea Smallholder Factories Plc \\
\hline $\mathbf{0 2}$ & Convenience Foods (Lanka) Plc & $2006 / 2007$ & $\mathbf{6 9}$ & Harischandra Mills Plc \\
\hline $\mathbf{0 3}$ & Keells Food Products Plc & $2010 / 2011$ & $\mathbf{7 0}$ & Cargills (Ceylon) Plc \\
\hline $\mathbf{0 4}$ & Kotmale Holdings Plc & $2006 / 2007$ & $\mathbf{7 1}$ & Lanka Milk Foods (Cwe) Plc \\
\hline $\mathbf{0 5}$ & Lankem Ceylon Plc & $2004 / 2005$ & $\mathbf{7 2}$ & CIC Holdings Plc \\
\hline $\mathbf{0 6}$ & MTD Walkers Plc & $2008 / 2009$ & $\mathbf{7 3}$ & Colombo Dockyard Plc \\
\hline $\mathbf{0 7}$ & Carsons Cumberbatch Plc & $2009 / 2010$ & $\mathbf{7 4}$ & Aitken Spence Plc \\
\hline $\mathbf{0 8}$ & Dunamis Capital Plc & $2008 / 2009$ & $\mathbf{7 5}$ & Sunshine Holdings Plc \\
\hline $\mathbf{0 9}$ & Richard Pieris And Company Plc & $2008 / 2009$ & $\mathbf{7 6}$ & $\begin{array}{l}\text { The Colombo Fort Land \& Building } \\
\text { Company Plc }\end{array}$ \\
\hline $\mathbf{1 0}$ & Asian Cotton Mills Ltd & $2005 / 2006$ & $\mathbf{7 7}$ & Samson International Plc \\
\hline $\mathbf{1 1}$ & Nawaloka Hospitals Plc & $2008 / 2009$ & $\mathbf{7 8}$ & Ceylon Hospitals Plc (Durdans) \\
\hline $\mathbf{1 2}$ & Associated Hotels Co. Ltd & $2006 / 2007$ & $\mathbf{7 9}$ & Browns Beach Hotels Plc \\
\hline $\mathbf{1 3}$ & Beruwala Walk Inn Plc & $2008 / 2009$ & $\mathbf{8 0}$ & Hotel Services (Ceylon) Plc \\
\hline $\mathbf{1 4}$ & Ceylon Hotels Corporation Plc & $2007 / 2008$ & $\mathbf{8 1}$ & Asian Hotels \& Properties Plc \\
\hline $\mathbf{1 5}$ & Citrus Leisure Plc & $2008 / 2009$ & $\mathbf{8 2}$ & Amaya Leisure Plc \\
\hline
\end{tabular}




\begin{tabular}{|c|c|c|c|c|}
\hline 16 & Galadari Hotels (Lanka) Plc & $2008 / 2009$ & 83 & John Keells Hotels Plc \\
\hline 17 & Hotel Sigiriya Plc & $2008 / 2009$ & 84 & Riverina Hotels Plc \\
\hline 18 & Hunas Falls Hotels Plc & $2008 / 2009$ & 85 & Kandy Hotels Company (1938) Plc \\
\hline 19 & Mahaweli Reach Hotels Plc & $2007 / 2008$ & 86 & Serendib Hotels Plc \\
\hline 20 & Marawila Resorts Plc & $2006 / 2007$ & 87 & Renuka City Hotel Plc \\
\hline 21 & Miramar Beach Hotel Plc & $2008 / 2009$ & 88 & Dolphin Hotels Plc \\
\hline 22 & Pegasus Hotels Of Ceylon Plc & $2008 / 2009$ & 89 & Royal Palms Beach Hotels Plc \\
\hline 23 & Sigiriya Village Hotels Plc & $2006 / 2007$ & 90 & The Lighthouse Hotel Plc \\
\hline 24 & Taj Lanka Hotels Plc & $2008 / 2009$ & 91 & Trans Asia Hotels Plc \\
\hline 25 & The Fortress Resorts Plc & $2008 / 2009$ & 92 & The Nuwara Eliya Hotels Company $p$ \\
\hline 26 & $\begin{array}{l}\text { Ceylon Guardian Investment } \\
\text { Trust Plc }\end{array}$ & $2006 / 2007$ & 93 & Ceylon Investment Plc \\
\hline 27 & Colombo Fort Investments Plc & $2008 / 2009$ & 94 & Colombo Investment Trust Plc \\
\hline 28 & $\begin{array}{l}\text { Environmental Resources } \\
\text { Investments Plc }\end{array}$ & $2009 / 2010$ & 95 & Guardian Capital Partners Plc \\
\hline 29 & Shaw Wallace \& Hedges Plc & $2008 / 2009$ & 96 & C T Land Development Plc \\
\hline 30 & $\begin{array}{l}\text { Colombo Land \& Development } \\
\text { Company Plc }\end{array}$ & $2005 / 2006$ & 97 & Property Development Plc \\
\hline 31 & East West Properties Plc & $2005 / 2006$ & 98 & Seylan Developments Plc \\
\hline 32 & Equity One Plc & $2008 / 2009$ & 99 & Serendib Land Plc \\
\hline 33 & Equity Two Plc & $2005 / 2006$ & 100 & Commercial Development Co. Plc \\
\hline 34 & Infrastructure Developers Plc & $2006 / 2007$ & 101 & $\begin{array}{l}\text { Cargo Boat Development Company } \\
\text { Plc }\end{array}$ \\
\hline 35 & Kelsey Developments Plc & $2010 / 2011$ & 102 & Touchwood Investment Plc \\
\hline 36 & $\begin{array}{l}\text { Huejay International Investments } \\
\text { Plc }\end{array}$ & $2009 / 2010$ & 103 & York Arcade Holdings Plc \\
\hline 37 & $\begin{array}{l}\text { City Housing \& Real Estate Co. } \\
\text { Plc }\end{array}$ & $2010 / 2011$ & 104 & On'ally Holdings Plc \\
\hline 38 & Abans Electricals Plc & $2007 / 2008$ & 105 & Acl Cables Plc \\
\hline 39 & Acme Printing \& Packaging Plc & $2004 / 2005$ & 106 & Ceylon Grain Elevators Plc \\
\hline 40 & Alufab Plc & $2005 / 2006$ & 107 & Piramal Glass Ceylon Plc \\
\hline 41 & Associated Electrical Cables & $2005 / 2006$ & 108 & Kelani Cables Plc \\
\hline 42 & $\begin{array}{l}\text { Blue Diamonds Jewellery } \\
\text { Worldwide Plc }\end{array}$ & $2010 / 2011$ & 109 & Bogala Graphite Lanka Plc \\
\hline 43 & Dankotuwa Porcelain Plc & $2006 / 2007$ & 110 & Lanka Ceramic Plc \\
\hline 44 & Hayleys Exports Plc & $2006 / 2007$ & 111 & Acl Plastics Plc \\
\hline 45 & Kelani Tyres Plc & $2009 / 2010$ & 112 & Sierra Cables Plc \\
\hline 46 & Lanka Aluminium Industries Plc & $2006 / 2007$ & 113 & Central Industries Plc \\
\hline 47 & Laxapana Batteries Plc & $2005 / 2006$ & 114 & Chevron Lubricants Lanka Plc \\
\hline 48 & Pelwatte Sugar Industries Plc & $2009 / 2010$ & 115 & Dipped Products Plc \\
\hline 49 & Regnis (Lanka) Plc & $2005 / 2006$ & 116 & Printcare Plc \\
\hline 50 & Richard Pieris Exports Plc & $2007 / 2008$ & 117 & Lanka Floor Tiles Plc \\
\hline 51 & Singer Industries (Ceylon) Plc & $2008 / 2009$ & 118 & Lanka Wall Tiles Plc \\
\hline 52 & Swadeshi Industrial Works Plc & $2006 / 2007$ & 119 & Tokyo Cement Company (Lanka) Plc \\
\hline 53 & Parquet(Ceylon) Plc & $2007 / 2008$ & 120 & Royal Ceramics Lanka Plc \\
\hline 54 & Diesel \& Motor Engineering Plc & $2005 / 2006$ & 121 & Sathosa Motors Plc \\
\hline 55 & Lanka Ashok Leyland Plc & $2006 / 2007$ & 122 & Colonial Motors Plc \\
\hline 56 & United Motors Lanka Plc & $2005 / 2006$ & 123 & The Autodrome Plc \\
\hline 57 & Kahawatte Plantations Plc & $2005 / 2006$ & 124 & Kegalle Plantations Plc \\
\hline 58 & Madulsima Plantations Plc & $2006 / 2007$ & 125 & Watawala Plantations Plc \\
\hline 59 & Udapussellawa Plantations Plc & $2004 / 2005$ & 126 & Talawakelle Tea Estates Plc \\
\hline 60 & Ceylon Printers Plc & $2004 / 2005$ & 127 & Kalamazoo Systems Plc \\
\hline 61 & Lake House Printers and & $2009 / 2010$ & 128 & Mercantile Shipping Company Plc \\
\hline
\end{tabular}




\begin{tabular}{|l|l|l|l|l|}
\hline & Publishers Plc & & & \\
\hline $\mathbf{6 2}$ & Paragon Ceylon Plc & $2006 / 2007$ & $\mathbf{1 2 9}$ & John Keells Plc \\
\hline $\mathbf{6 3}$ & Gestetner Of Ceylon Plc & $2006 / 2007$ & $\mathbf{1 3 0}$ & Colombo Pharmacy Company Plc \\
\hline $\mathbf{6 4}$ & Ceylon \& Foreign Trades Plc & $2005 / 2006$ & $\mathbf{1 3 1}$ & Eastern Merchants Plc \\
\hline $\mathbf{6 5}$ & Radiant Gems International Plc & $2005 / 2006$ & $\mathbf{1 3 2}$ & C. W. Mackie Plc \\
\hline $\mathbf{6 6}$ & Singer Sri Lanka Plc & $2005 / 2006$ & $\mathbf{1 3 3}$ & Brown \& Company Plc \\
\hline $\mathbf{6 7}$ & Tess Agro Plc & $2010 / 2011$ & $\mathbf{1 3 4}$ & Office Equipment Plc \\
\hline
\end{tabular}

\section{Appendix B: Case Wise Results of the Model}

\begin{tabular}{|c|c|c|c|c|c|c|c|}
\hline $\begin{array}{l}\text { Company } \\
\text { No }\end{array}$ & $\begin{array}{l}\text { Actual } \\
\text { Group }\end{array}$ & $\begin{array}{l}\text { Predicted } \\
\text { Group }\end{array}$ & Z-score & $\begin{array}{l}\text { Company } \\
\text { No }\end{array}$ & $\begin{array}{l}\text { Actual } \\
\text { Group }\end{array}$ & $\begin{array}{l}\text { Predicted } \\
\text { Group }\end{array}$ & Z-score \\
\hline 1 & 0 & 0 & .242 & 40 & 0 & 0 & 1.551 \\
\hline 2 & 1 & 1 & -.395 & 41 & 0 & 0 & .352 \\
\hline 3 & 1 & $0^{* * *}$ & 1.493 & 42 & 0 & 0 & .049 \\
\hline 4 & 0 & 0 & 2.018 & 43 & 0 & 0 & .025 \\
\hline 5 & 1 & $0^{* * *}$ & .492 & 44 & 1 & $0^{* *}$ & .070 \\
\hline 6 & 1 & 1 & -1.167 & 45 & 1 & 1 & -1.702 \\
\hline 7 & 0 & $1^{\text {** }}$ & -.061 & 46 & 1 & 1 & -2.031 \\
\hline 8 & 0 & 0 & .539 & 47 & 0 & 0 & .768 \\
\hline 9 & 0 & 0 & .341 & 48 & 0 & 0 & .625 \\
\hline 10 & 1 & 1 & -.868 & 49 & 0 & 0 & .642 \\
\hline 11 & 1 & 1 & -.319 & 50 & 1 & $0^{* *}$ & 1.154 \\
\hline 12 & 0 & 0 & .867 & 51 & 0 & 0 & 1.058 \\
\hline 13 & 0 & 0 & .878 & 52 & 1 & $0^{* * *}$ & .926 \\
\hline 14 & 1 & $0^{* * *}$ & 2.389 & 53 & 0 & 0 & .468 \\
\hline 15 & 1 & 1 & -1.447 & 54 & 1 & $0^{* *}$ & .419 \\
\hline 16 & 1 & 1 & -.483 & 55 & 0 & 0 & 3.299 \\
\hline 17 & 0 & 0 & .855 & 56 & 1 & $0^{* * *}$ & .774 \\
\hline 18 & 0 & 0 & .592 & 57 & 0 & 0 & 1.241 \\
\hline 19 & 1 & 1 & -2.554 & 58 & 1 & 1 & -.986 \\
\hline 20 & 0 & $1^{* *}$ & -.458 & 59 & 1 & 1 & -.683 \\
\hline 21 & 1 & 1 & -.844 & 60 & 1 & $0^{* *}$ & 1.996 \\
\hline 22 & 0 & $1^{* *}$ & -.428 & 61 & 1 & 1 & -.060 \\
\hline 23 & 0 & 0 & .289 & 62 & 1 & 1 & -.466 \\
\hline 24 & 1 & 1 & -.638 & 63 & 1 & 1 & -1.617 \\
\hline 25 & 1 & 1 & -2.668 & 64 & 1 & 1 & -2.154 \\
\hline 26 & 0 & 0 & .167 & 65 & 1 & 1 & -1.324 \\
\hline 27 & 1 & 1 & -.139 & 66 & 0 & 0 & .787 \\
\hline 28 & 1 & 1 & -1.018 & 67 & 0 & 0 & .437 \\
\hline 29 & 0 & 0 & .278 & 68 & 0 & 0 & 1.013 \\
\hline 30 & 1 & 1 & -2.307 & 69 & 0 & 0 & 1.536 \\
\hline 31 & 0 & 0 & .815 & 70 & 0 & $1^{* *}$ & -.352 \\
\hline 32 & 1 & 1 & -.940 & 71 & 0 & $1^{* *}$ & -.039 \\
\hline 33 & 1 & 1 & -1.231 & 72 & 0 & 0 & 1.492 \\
\hline 34 & 0 & $1^{\text {*** }}$ & -.580 & 73 & 0 & 0 & .524 \\
\hline 35 & 0 & $1^{\text {*** }}$ & -.167 & 74 & 1 & $0^{* *}$ & .208 \\
\hline 36 & 1 & 1 & -1.002 & 75 & 0 & 0 & 1.655 \\
\hline 37 & 1 & 1 & -2.010 & 76 & 0 & 0 & .966 \\
\hline 38 & 1 & 1 & -.951 & 77 & 1 & 1 & -.489 \\
\hline 39 & 1 & 1 & -1.232 & 78 & 1 & 1 & -2.413 \\
\hline
\end{tabular}




\begin{tabular}{|c|c|c|c|c|c|c|c|}
\hline $\begin{array}{l}\text { Company } \\
\text { No }\end{array}$ & $\begin{array}{l}\text { Actual } \\
\text { group }\end{array}$ & $\begin{array}{l}\text { Predicted } \\
\text { Group }\end{array}$ & Z-score & $\begin{array}{l}\text { Company } \\
\text { No }\end{array}$ & $\begin{array}{l}\text { Actual } \\
\text { group }\end{array}$ & $\begin{array}{l}\text { Predicted } \\
\text { Group }\end{array}$ & Z-score \\
\hline 79 & 1 & $0^{* *}$ & 1.488 & 107 & 0 & 0 & .720 \\
\hline 80 & 1 & 1 & -2.131 & 108 & 0 & 0 & .492 \\
\hline 81 & 0 & 0 & .693 & 109 & 1 & $0^{* * *}$ & .377 \\
\hline 82 & 0 & 0 & 1.623 & 110 & 1 & $0^{* *}$ & 1.478 \\
\hline 83 & 0 & $1^{* *}$ & -1.563 & 111 & 0 & 0 & .554 \\
\hline 84 & 0 & 0 & 1.657 & 112 & 1 & $0^{* * *}$ & .187 \\
\hline 85 & 1 & 1 & -1.913 & 113 & 1 & 1 & -1.531 \\
\hline 86 & 0 & 0 & .400 & 114 & 0 & $1^{* *}$ & -.010 \\
\hline 87 & 1 & $0^{* * *}$ & .216 & 115 & 1 & 1 & -1.236 \\
\hline 88 & 0 & 0 & 1.004 & 116 & 0 & 0 & .254 \\
\hline 89 & 1 & 1 & -.615 & 117 & 1 & 1 & -1.788 \\
\hline 90 & 1 & $0^{* * *}$ & .247 & 118 & 0 & 0 & .032 \\
\hline 91 & 0 & 0 & .446 & 119 & 1 & 1 & -1.029 \\
\hline 92 & 0 & 0 & 1.358 & 120 & 0 & 0 & 1.718 \\
\hline 93 & 0 & 0 & 1.016 & 121 & 0 & 0 & .575 \\
\hline 94 & 1 & 1 & -1.493 & 122 & 1 & 1 & -.068 \\
\hline 95 & 1 & 1 & -1.092 & 123 & 0 & 0 & .263 \\
\hline 96 & 0 & 0 & 1.022 & 124 & 1 & 1 & -1.694 \\
\hline 97 & 0 & 0 & .559 & 125 & 0 & 0 & 1.783 \\
\hline 98 & 1 & 1 & -1.111 & 126 & 1 & 1 & -1.528 \\
\hline 99 & 1 & 1 & -1.863 & 127 & 0 & 0 & .475 \\
\hline 100 & 0 & 0 & .720 & 128 & 0 & $1^{* *}$ & -.552 \\
\hline 101 & 0 & 0 & 1.004 & 129 & 1 & $0^{* *}$ & 1.036 \\
\hline 102 & 0 & $1^{* * *}$ & -.039 & 130 & 0 & 0 & .322 \\
\hline 103 & 1 & $0^{* * *}$ & .494 & 131 & 0 & 0 & 2.126 \\
\hline 104 & 1 & $0^{* * *}$ & .619 & 132 & 1 & 1 & -2.811 \\
\hline 105 & 0 & 0 & .946 & 133 & 1 & $0^{* *}$ & .556 \\
\hline 106 & 1 & 1 & -1.974 & 134 & 1 & 1 & -.486 \\
\hline
\end{tabular}

** Misclassified cases 


\section{Appendix C: Discriminant Distribution}
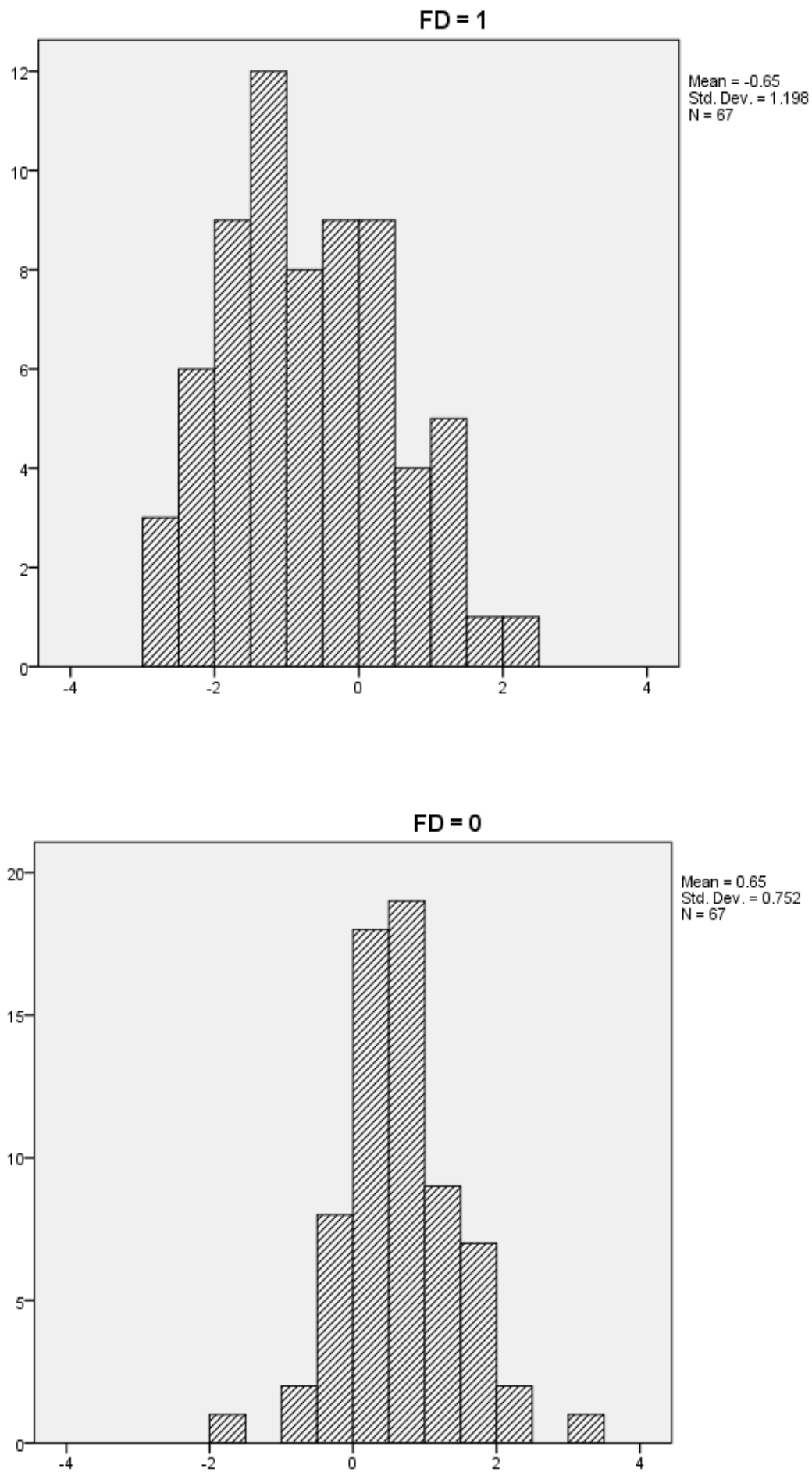

Note: FD- $1=$ Distress group, FD- $0=$ Non-distress group 